Thus far, scholarly studies of the anti-nuclear movement have focused on its moderate, mainstream forces and their interaction with public policy. Therefore, Harvey's emphasis on debate and organizational dynamics within the broader nuclear disarmament campaign fills a gap in the scholarly literature.

To make his case, Harvey draws upon numerous relevant manuscript collections, personal interviews with key activists of the era, periodicals, and published sources. He also employs a carefully-reasoned analysis, as well as a sophisticated writing style. Consequently, American Anti-Nuclear Activism, 1975-1990 emerges as a well-crafted, well-researched, and credible scholarly work. In summary, this book is an important contribution to existing scholarship on peace and disarmament movements and, more generally, to the scholarship on social movements.

Lawrence S. Wittner

Professor of History Emeritus State University of New York at Albany

Albany, NY I 2222, USA

E-mail: lwittner@albany.edu

Zhang, Lu. Inside China's Automobile Factories. The Politics of Labor and Worker Resistance. Cambridge University Press, New York [etc.] 201 5. xvi, 240 pp. Ill. \$95.00; £60.00; RMB 537.50. doi:10.1017/S002085901 5000620

In view of its rapid capitalist transformation, China's labour and industrial relations have attracted increased attention from scholars in recent years. In the growing body of literature on this topic, Lu Zhang's book is, to my knowledge, the first comprehensive study of labour relations in the Chinese automotive industry. As this industry is generally understood to be a forerunner in the development of labour relations, has been labelled "strategic" by the Chinese state, and has become a hotbed of worker activism, her work makes for a timely and highly relevant contribution to the field.

Zhang's stated aim is to understand the conditions, subjectivity, and collective actions of workers in China's car assembly industry. The core of her research consists of more than 300 interviews, as well as documents and observations, gathered from extensive fieldwork in the assembly plants of state-owned enterprises and Sino-foreign joint ventures over a seven-year period, 2004-20II. Zhang analyses her observations against the background of the structural transformation of China's automotive industry, seeking to explain the relationship of structure and subjectivity in working-class formation in China.

Framed by an introduction and a conclusion, Zhang's argument proceeds in six chapters, starting with an analysis of the most general structural conditions and transformations of the Chinese automotive industry, proceeding to the labour market and the social composition of the work force, the organization of production and the social order within factories, and finally to the concrete subjectivity, motivations, and actions of formally employed workers on the one hand and temporary workers on the other. Additionally, Zhang discusses the strategies of the state in dealing with an increasingly restive working class.

A recurring theme and point of reference throughout Zhang's analysis is how the capitalist development of the automotive industry has fostered conditions that at the same 
time exacerbate pressure for increased competitiveness and profitability, whilst creating the opportunity structures and consciousness that allow for intensified worker activism. In this context, Zhang shows throughout her book how party-state, management, and workers negotiate a trilateral relationship characterized by the contradiction of "legitimacy and profitability” (p. I I), and how each employ specific strategies in the process. In doing so, Zhang also demonstrates that it is ultimately the party-state that makes the rules and draws the boundaries within which class relationships are negotiated, as it seeks political legitimacy in its ability to balance rapid capitalist development and social peace and stability.

As a "strategic" or "pillar industry", the automotive sector has been at the centre of the Chinese party-state's efforts to create globally competitive industries. As Zhang discusses in chapter 2, up until the I990s, state-owned enterprises and Sino-foreign joint ventures alike, were still strongly influenced by the legacies of socialism, such as management incentives shaped by soft budget constraints and hegemonic factory regimes. The state-led policies of staff reductions, China's ascension to WTO membership, as well as the emergence of new Chinese companies, however, have made competitiveness and profitability the prime motivators of the industry's development since the turn of the twenty-first century.

The drive for continued increases in productivity that has thus been created has led to a fundamental remaking of the industry's labour relations. The labour market conditions and hiring practices on the one hand, and the (re-)organization of production in the factory on the other, are discussed by the author in chapters 3 and 4 .

The central strategy of management to deal with the capital-labour contradiction is by means of what Zhang describes as "labour force dualism", the widespread use of split workforces of formally employed and temporary employees in car assembly plants. While both groups generally fulfil the same work on the assembly line, temporary workers earn less and have less secure employment than their formally employed colleagues. In the locations surveyed by Zhang, established workers make up as little as one-third of the workforce, whereas the mass of temporary workers is drawn from labour dispatch agencies and as interns from vocational schools. Zhang here makes two important observations that qualify previous research: first, the old boundaries drawn by official residence through household registration (bukou) is of diminishing importance for workforce segmentation, giving way to more arbitrary, and thus more contentious divisions; second, the large share of underprivileged temporary workers and their associated workplace grievances lead Zhang to reject the thesis that Chinese automotive workers are generally more quiescent due to favourable wage and work conditions.

The organization and relations of production in the assembly sector of the Chinese automotive industry are now generally characterized by methods such as just-in-time inventory systems and Taylorist/Fordist lean (and "mean") production techniques. These intermix with specific "Chinese characteristics" of production, such as "human wave tactics", "by which automakers mobilize large numbers of young, relatively low cost workers to work long hours at intense pace on assembly lines, along with incremental mechanization to maximize output" (p. 91). Zhang also describes how work groups and their team leaders are continuously pressured to improve quality and productivity. Here, as in other parts of the book, Zhang's interviews and observations make for vivid descriptions of work on the assembly line, which is characterized by a heavy workload, long hours, intense pace, and excessive overtime, which the mostly young auto workers are made to endure by refined methods of social and ideological control. Such harsh working conditions combined with limited opportunities for career enhancement in a hierarchical 
factory social order, however, also increase workers' grievances and, ultimately, their militancy, which Zhang discusses for both formally employed and temporary workers in chapters 5 and 6.

As a strategy of social control, labour-force dualism creates differentiated grievances, coping strategies, and forms of resistance in the segmented work force. While subject to the same working conditions, formally employed workers enjoy higher wages and, thanks to the "buffer" of temporary workers, relatively high job security even in times of crisis. Still, they are employed on fixed-term renewable contracts, and, for fear of losing their relatively privileged positions, are thus less inclined to turn to overt forms of resistance to address their grievances. Furthermore, Zhang finds that management, in collusion with enterprise party committees and unions, employs sophisticated, cultural, and ideological methods of control of formally employed workers, attempting to build a hegemonic position in their relations with the core workforce. As work on the line becomes harder and opportunities for upward mobility remain limited, the gap between hegemonic rhetoric and work reality has in some cases led formally employed workers to resort to strategies such as reducing effort to bargain for better conditions, appealing to ideology, pilferage and sabotage, and sit-down strikes to win concessions from management. The vulnerability of the modern production methods to even limited and localized forms of resistance greatly enhances the bargaining power of workers. Overt collective action, however, remains a rarity among formally employed workers, who prefer to resort to individual coping strategies.

Contrary to some expectations, Zhang finds that in the factories studied temporary workers are more militant and more willing to resort to collective action than their established counterparts, not despite but because of their more precarious position, especially as they perceive the labour-force dualism to be a blatant violation of the equal pay for equal work principle. Forms of resistance by this group include sabotage, slowdowns, absenteeism, the collective quitting of jobs, and overt strikes, which the often very young workers organize in factory dormitories and through social media. Formally employed workers may join such action if common interests are at stake. Even when this is not the case, Zhang asserts that the relationship between the two groups is not characterized by antagonism, but rather by detachment. Against this background, labor-force dualism appears to have become less useful as a tool for control, and has in itself become a source of workers' grievances and militancy.

Finally, in chapter 7 , Zhang returns to discussing the role of the state in shaping labour relations. As Zhang insists throughout the book, the party-state's policies have shaped the development trajectory of the automotive industry and have drawn the boundaries that enabled labour-force dualism to be used as a strategy to deal with the contradictory goals of profitability and legitimacy. Responding to increased labour conflict, the state continues to attempt to balance this contradiction, for example in the 2008 Labour Contract Law, in which it renegotiates, re-regulates, but ultimately also entrenches labour-force dualism.

In summary, Zhang demonstrates in her study how the capitalist development of the Chinese automotive industry, the introduction of modern production techniques, and the detrimental effects of competitive pressures on the workforce have contributed to a growing class-consciousness among formally employed and temporary workers alike, though their struggles so far remain localized and limited to specific aims. Her analysis also demonstrates how the strategies of management and the policies of the party-state have, to a certain extent, managed to address grievances and mediate worker militancy. Such strategies and policies can, however, only provide temporary fixes, as they themselves become subject to the 
moving contradictions they are supposed to negotiate, as is made evident in Zhang's analysis of labour-force dualism.

Lu Zhang's book provides a comprehensive overview of the development of labour relations in the assembly sector of China's automotive industry, which she supports by rich empirical material gathered from her fieldwork and by referencing a broad body of English and Chinese research literature. More importantly, however, her work truly distinguishes itself by her thorough, theoretically informed analysis of the subject matter, being at all times keenly aware of the dynamic and contradictory character of the relationship between workers and management in capitalism in general, and the important role played by the party-state in the Chinese automotive industry in particular.

\section{Robert Pauls}

Faculty of East Asian Studies, Ruhr-Universität Bochum Universitätsstraße I 50, 44780 Bochum, Germany E-mail: robert.pauls@ruhr-uni-bochum.de

Huws, Ursula. Labor in the Global Digital Economy. The Cybertariat Comes of Age. Monthly Review Press, New York (NY) 2014. 208 pp. \$19.00. doi:10.1017/S0020859015000632

With the seven brief but powerful essays reprinted in Labor in the Global Digital Economy, Ursula Huws has provided a clear and compelling summary of the evolution of networked capitalism over the first fifteen years of the twenty-first century, raising important questions about the prospects for both waged and unwaged workers all across the global division of labor. The book is a sequel of sorts to her earlier collection of essays, The Making of a Cybertariat: Virtual Work in a Real World (New York, 2003). Two chapters focus in detail on what might be called "creative labor", "virtual production", or "knowledge work"; however, the strength of this book is that it situates such supposed "new economy" actors and organizations within a longer line of political-economic analysis and empirical datagathering on these fields. As Huws makes clear, already some ten to fifteen years ago several research projects tried to come to terms with these changes in the world of work, especially the "Estimation and Mapping of Employment Relocation in a Global Economy in the New Communications Environment" project ("EMERGENCE", launched in 2000) and the "Work Organization Restructuring in the Knowledge Society" project ("WORKS", launched in 2005).

Rather than focusing attention solely on the networked, algorithmic tools that both augment and replace human labor in this story, Huws challenges us to think about the areas of human experience to which those tools and those laborers are now being mobilized, in the service of the accumulation of private capital rather than the stewardship of the public interest: the circulation of arts and culture, the provision of public services, and even the performance of the daily social practices that bind families, friends, and communities. In each of these arenas, incorporation into capitalist profit-making strategies and institutions means that a crucial space for critical challenge to those same strategies and institutions may be diluted, damaged, or even lost altogether, with "consumers" being created out of what 